\title{
Measuring the effect of disclosure quality of integrated business reporting on the predictive power of accounting information and firm value
}

\author{
Magdy Abdul Hakim Melegya and Alaa Mohamad Malo Alain ${ }^{\text {b* }}$
}

aAssistant Professor, Department of Accounting, Faculty of Commerce, Benha University, Egypt

${ }^{b}$ Professor, Department of Accounting, Faculty of Aqaba College, Al-Balqa Applied University, Jordan

\begin{tabular}{l}
\hline C H R O N I C L E \\
\hline Article history: \\
Received: October 3, 2019 \\
Received in revised format: No- \\
vember 12 2019 \\
Accepted: November 15, 2019 \\
Available online: \\
November 16, 2019 \\
\hline Keywords: \\
Integrated Business Reports \\
Accounting Conservatism \\
Share Prices \\
Discretionary Accruals \\
Firm Value
\end{tabular}
A B S T R A C T

\begin{abstract}
This paper measures the effect of disclosure quality of integrated business reports on the predictive power of accounting information and firms' value in the Egyptian Stock Market. In order to achieve the research objectives, the research relies on content analysis approach in examining the annual reports of the companies listed in the Egyptian Stock Exchange from 2015 to 2018. The study depends on measuring the independent variable i.e. disclosure quality of the integrated business reports on building up a disclosure index consisting of 45 items in 8 groups equally weighted, whereas; dependent variables which represents the predictive power of accounting information measured by adopting three different methodologies; namely Accounting Conservatism, Share Prices, and Discretionary Accruals. Concerning to firm value, the study uses Tobin's Q model to measure the relationship between the quality disclosure of the integrated business reports and the firm value. The results indicate that the quality disclosure of integrated business report leads to increase accounting conservatism and share prices, whereas the statistics analysis reports a negative effect towards discretionary accruals indicating that the quality disclosure of integrated business report leads to decrease in discretionary accruals.
\end{abstract}

(C) 2020 by the authors; licensee Growing Science, Canada

\section{Introduction}

Over the last ten years, the Integrated business Reporting (IBR) witnessed a growing concern, with big corporate migrating from the traditional approach of reporting, which highlight on financial indicators, to a more integrated approach of reporting that highlighted all aspects of the business. According to Financial Reporting Council. (2011) "Financial Reports were becoming more cluttered, more complex and less relevant to shareholders". Although many companies provided more of nonfinancial information through sustainability reports and corporate social responsibility (CSR) reports, but still these reports were not able to provide the financial and non-financial information in an integrated manner to enhance shareholders' understanding of the company's performance (Lee \& Yeo, 2016). These reports are often formulated in an isolation from each other and naturally resulting their failure to link sustainability issues with the company's strategy. Therefore, accounting literature assures to adopt the approach of integrated business reports by firms as a mean of delivering financial and non-financial information on social and environmental responsibility and corporate governance, as well as information on corporate strategy, provided that this information, whether historical or future, has to be clearly formulated, concise, coordinated and feasible to enhance the predictive power of accounting information and achieve comparability (Rinaldi et al., 2018; Lopes \& Coelho, 2018) . Consistence to this view, IIRC (2013) explains Integrated Reporting (IR) report as "an integrated report which is a * Corresponding author. Tel.: +962-799159412

E-mail address: prof.maloain@bau.edu.jo (A. Mohamad Malo Alain) 
concise communication about how an organization's strategy, governance, performance, and prospects, in the context of its external environment, lead to the creation of value in the short, medium and long term". Integrated business reports are gaining widespread attention and acceptance in most countries of the world. There is strong support from the professional accounting and auditing bodies in many countries. The B20 report of the Business Forum has clearly referred to integrated business reports as a key innovation which would make corporate reports more relevant to long-term investments as IBR provides a more holistic view on how to create value over time by providing more insights into business strategies, performance and expectations in corporate reports (Lee \& Yeo, 2016). International Integrated Reporting Council (IIRC) has emphasized that the objective of these reports is to improve the quality of information available to capital providers to optimize the allocation of resources in a more efficient and effective manner and to increase the firm value (IIRC, 2013). With regard to integrated business reports in the Egyptian environment, although there is an interest in non-financial reports, the Center of Egyptian Managers, in cooperation with the Egyptian Stock Exchange and Standard \& Poor's, prepared the Egyptian Corporate Responsibility Index in 2010, in addition to the issuance of disclosure guide in regard to sustainability performance. However, the disclosure of integrated business reports has not received sufficient attention as it is still limited and does not follow a specific model, and has not yet issued an accounting standard that regulates its accounting treatment, in addition to lack of preparing a standardized format for the integrated report. Highlighting Egyptian business environment, this research aims to empirically examine and to investigate the effect of disclosure quality of integrated business reports on the predictive power of accounting information through three different methodologies i.e. (Accounting Conservatism, Discretionary Accruals, and Share Prices) and firm value. Therefore, the current research gained its importance by providing an evidence from the Egyptian business environment to develop an index to measure the disclosure quality of integrated business reports, and ultimately providing an important information that will help accounting standards makers and decision makers in the Egyptian business environment to take necessary decisions, legislation or rules, which could motivate companies to pay attention to the disclosure quality of integrated business reports, increase transparency and give a good picture to stakeholders .

\section{Theoretical Background, Literature Review and Research Development}

Today management responsibilities have taken different shapes and tasks, in particular with regard to fulfilling the needs of stakeholders with relevant information for decision making. Therefore, IIRC has produced a framework called integrated reporting (IR) to satisfy and answer all necessary information required by stakeholders and the wider community that can describe short-term and long-term corporate sustainability. Consistent to this view, Macias and Farfan-Lievano (2017) describe that $<\mathrm{IR}>$ enables the companies to enhance the informational content with regard to sustainability strategies to stakeholders in order to find various mechanisms for value creation. With respect to this latter, the predictive power of accounting information, and firm value seem to have an effect on the adoption of integrated business reporting as witnessed by various studies. In this sense, Qiu et al. (2016) and Cheng and Kung (2016) concluded that the disclosure of social activities positively affects the market value of companies and ultimately increases the expected growth rates from the cash flows of these companies, and encourage the adoption of conservative accounting policies. In contrast to this, Badawi (2017) found insignificant relationship between institutional ownership and the level of corporate disclosure of social responsibility and the firm's value from the investors' view point. Indeed, Iredele (2019) clearly assures that firms vary in disclosing the level of quality of their integrated reports based on the several factors i.e. differences in profitability, board size, gender and firm size. No significant relationship was found between quality of integrated reports and leverage. Ferrero et al. (2016) found that companies with a high degree of conservatism, high quality of accruals, and low earning management practices characterized by high quality of financial reporting tend to increase disclosure of sustainability information. As far as the relationship between information asymmetry and disclosure of integrated business reports, García-Sánchez and Noguera-Gámez (2017) came up into a negative relationship between these variables, as integrated business reports contribute to minimize agency challenges, facilitating decision-making, and satisfying investors. On the other side, Fuhrmann et al. (2017) concluded that the preparation of highquality assertions for sustainability reports reduces the level of asymmetry of information and increases its predictive power.

One more recent strand of literature concluded that integrated reports enhances corporate disclosure and reduces information asymmetries; increases the quality of reported earnings per share (Cortesi \& Vena, 2019). On the other hand, Lee and Yeo (2016) found that there is a positive correlation between disclosure of integrated business reports and the firm's value, as this kind of disclosure contributes to reduce the cost of information processing in the complex and informative operational environment, reducing information asymmetry between internal and external parties. These results supported by Barth et al. (2017), where business reports had a positive impact on both liquidity and expected future cash flows, while they did not find any relationship between the reports and the cost of capital. Regarding non-financial disclosure through integrated business reports and its role in enabling investors to evaluate firms power in creating value, Sharaf, (2015) came into conclusion that there is an increasing trend for such kind of integrated reports as it provides both financial and non-financial information for investors where traditional report cannot do that, and this may contribute to enable investors to evaluate firms and its power to create value. Further, $\mathrm{Li}$ et al. (2017) found that disclosure of integrated business reports helps to improve disclosure and transparency levels, better evaluating the company's performance, and then evaluating its viability and expansion.

\subsection{Nature of Research Problem}

Now a days Companies are exposed to strong external pressures to disclose their transactions with non-financial issues. Traditional and financial indicators that ignore non-financial information are no longer sufficient for stakeholders to form a comprehensive picture of the company's performance and ability to create value (Kilic \& Kuzey, 2018). Current corporate reports 
do not contribute to critical interdependence between strategy, governance, operations, financial and non-financial performance, so integrated reports have emerged as a reaction to these criticisms and as a device of treating shortcomings in the conventional reports (IIRC, 2011; Feng et al., 2017). Therefore, the research problem may be summarized by the following questions:

a) What is the level of disclosure quality of integrated business reports in the Egyptian business environment in the light of the guidelines issued by the International Integrated Reporting Council and the principles of financial reporting GR1?

b) Does the disclosure quality of integrated business reports affect the predictive power of accounting information (Accounting Conservatism, Discretionary Accruals , share prices?

c) Does the disclosure quality of integrated business reports affect the firm's value listed in the Egyptian Stock Exchange?

\section{Development of Research Hypothesis}

\subsection{Accounting Conservatism}

Accounting conservatism improves the disclosure quality of integrated business reports as it may bring many benefits i.e. reducing agency problems, reducing managers' motivation to overestimate earning, and reducing information asymmetry between management and external owners (Cortesi \& Vena, 2019). It reduces the likelihood of managers withholding information from expected losses, and also reduces the moral hazards that arise from agency conflicts such as aggressive profit management, which is reflected in improving both the utility of financial reporting and the firm value. Essentially, the motivation for the disclosure of integrated business reports is to obtain recognition and endorsement from stakeholders and to reduce (increase) the rejection (approval) of stakeholders. For example, providing high-quality earnings information is considered as a social responsibilities activities which is minimizing agency problems and reducing information asymmetry, and therefore social responsibilities is expected to play an alternative role to governance processes to enhance transparency of financial information and reliability of financial reporting. Cheng and Kung (2016) noted that corporate disclosure of integrated business reports was positively correlated with earnings conservatism, which reinforces moral imperative, restricts the opportunistic behavior of managers and thus increases the quality of profits, and contributes to creating a positive management image. It includes some other activities that reflect the real economic substance of the enterprise. Thus, in the absence of conclusive results regarding the relationship between disclosure quality of integrated business reports and the accounting conservatism, the first hypothesis can be formulated as follows:

$\mathrm{H}_{1}$ : There is a statisticlly positve association between the quality disclosure of the integrated business reports and the accounting conservatism.

\subsection{Discretionary Accruals}

In accounting literature there is controversy issues about the effect of informational content for integrated business reports on profit management. Mahmood and Humphrey (2013) noted that despite the fact that maximizing profits will enhance a company's financial performance, it can adversely affect the views of stakeholders in general and lead to adverse effects on the company's long-term growth and sustainability. There is a need for a comprehensive overview of the company's performance and expansion, and not only to focus on financial performance but to the environmental, social performance, risks and good governance practices which is provided by integrated business reports. Maso et al. (2017) found that the informational content of these reports reduces information asymmetry, which is reflected in reducing profit management practices and improve performance and reputation of the company. In the light of the previous controversy regarding the relationship between disclosure of integrated business reports and profit management, the second hypothesis could be formulated as follows:

$\mathrm{H}_{2}$ : There is a statistically negative association between the quality disclosure of the integrated business reports and the discretionary accruals.

\subsection{Share Prices}

Cormier and Magnan (2007) noted that disclosure of integrated business report is essential in activating the performance of financial markets as it leads to increase transparency and reduce the degree of uncertainty, which allows investors to make more accurate estimates of profits and cash flows in the future, and is reflected in determining share prices more accurately. In this context, Abdul Aal (2018) pointed out that the disclosure of integrated business reports contributes to increase the efficiency of the stock market as this disclosure contributes to do a balance between share prices and the associated risks, and therefore this disclosure reduces fluctuating in share prices. In contrast, Cormier et al. (2005) indicated that if integrated business reporting information is not provided, investors may bear the worst case scenario and ultimately demanding for price reduction who are ready to pay for investing in company's shares. Thus, in the absence of conclusive results regarding the relationship between disclosure quality of integrated business reports and the share price, the third hypothesis can be formulated as follows:

$\mathrm{H}_{3}$ : There is a statistically positive association between the quality disclosure of the integrated business reports and the share price. 


\subsection{Firm value}

There are two views pertaining to the relationship between disclosure of integrated business reports and firm value (Lee \& Yeo, 2016). First view suggests that integrated business reports are beneficial to investors and are expected to positively correlate with the firm value resulting improving the quality of information provided to investors enabling them to allocate capital in a more efficient and productive manner. The second view suggests that disclosure of integrated reports may harm the interests of shareholders, therefore, it is expected to have a negative effect between disclosure and firm value (Lee \& Yeo, 2016), as it is associated with costs such as the cost of strategic competitor information, business models and potential legal obligations (Arya, et al., 2010). In accounting literature, Haryono and Liskandar,(2015) concluded that disclosure of social and environmental activities through integrated business reports positively affects the performance of the company and reduces future risks leading to increase firm value. In this context, Zeng (2016) found that the disclosure of these activities is connected mainly by management and its desire to reduce abusive practices which enhances the firm value, while Badawi (2017) did not find any significant relationship between disclosure of social responsibility and the firm value from the perspective of investors in Egypt. Thus, in the absence of conclusive results regarding the relationship between disclosure quality of integrated business reports and the firm value, the fourth hypothesis can be formulated as follows:

$\mathrm{H}_{4}$ : There is a statistically positive association between the quality disclosure of the integrated business reports and the firm value.

\section{Research Methodology and Research Model}

Researchers adopted the inductive approach in reviewing the accounting literature related to the disclosure quality of integrated business reports in order to enrich the research theoretical framework, and the deductive approach to explore the relationship between the quality of disclosure of integrated business reports and both the predictive power of accounting information and the firm value. Content analysis approach has been also adopted in examining annual reports of companies listed on the Egyptian Stock Exchange in the EGX 30 index during the period from 2015 to 2018, to develop models and test research hypotheses.

\subsection{Conceptual Model}

Fig. 1 shows the key variables of this research: This research focuses mainly on measuring the relationship between disclosure quality of the integrated business reports and the accounting conservatism, discretionary accruals, share prices and firm's value.

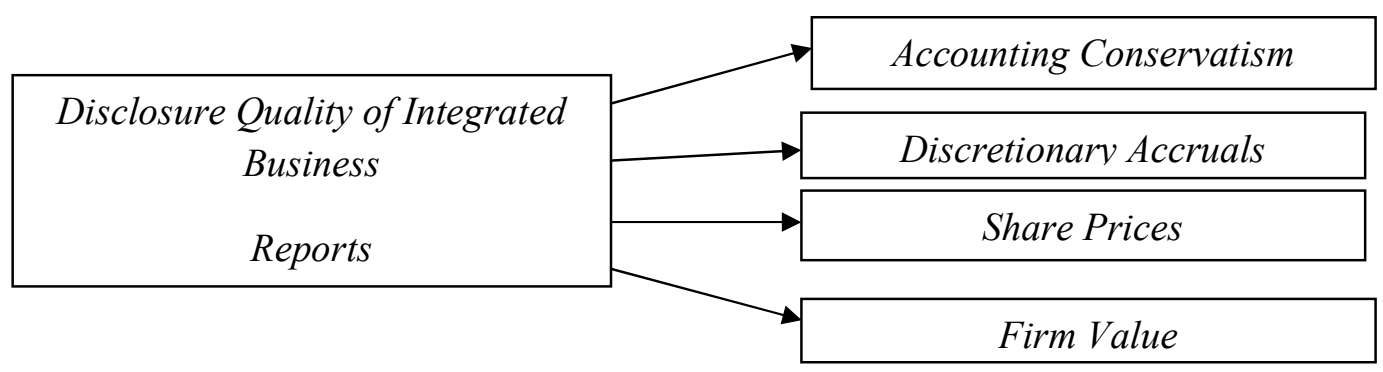

Fig. 1. Conceptual model of hypothesized relationships

\subsection{Measurement of Dependent Variables}

Dependent variables represent the following.

The predictive power of accounting information: the researchers have adopted three different methodologies:

Conservatism (CONS): was measured using the Book-to-Market Ratio (MTB) model provided by the Beaver and Rya, (2000) and is the most widely used measure in accounting literature due to the availability, ease of use and accuracy of model variables and it is calculated as follows:

$$
\text { Cons }=M V \div B V \text {, }
$$

where: (MVit): The market value of equity of firm $i$ in the end of year $t$. (BVit): The Book value of equity of firm $i$ in the end of year $t$. The ratio of the market value of the company's equity is measured by the number of shares traded multiplied by the market price of the stock, which is the closing price at the end of the accounting period. The increase in the ratio of the market value to book value is an indication of the increase in the degree of conservatism, while the decrease in this ratio indicates the low degree of conservatism.

\section{Discretionary Accruals (DAC)}

The researchers used a model by Jones (1991) modified by Dechow et al. (1991) to measure discretionary accruals in Egyptian business environment. Thus, discretionary accruals can be calculated through the following steps: 
The aggregate accrual is measured by the cash flow method by the difference between net income before extraordinary items or income after interest, tax and cash flow from operating operations.

$$
T A_{i t}=I B E I_{i t}-C F O_{i t}
$$

where: $i$ represents the company, $t$ represents the year that concerns the variable, and is confined between $2015,2016,2017$ and 2018), (TA) represents the company's total accrual accounts $(i)$ during the period $t, I B X_{i t}$ represents income before unordinary items, or income after interest and taxes of the company $(i)$ in year $(t)$, and $C F O_{i t}$ represents cash flows from the operating activities for company $(i)$ per year $(t)$.

Regression model for the group of variables affecting Total Accruals (TA)

The proposed model was used by Kothari et al. (2005) which is an amendment to the Jones (1991) model of the company's financial performance and is called Performance-Matched (PM). According to this model, the regression equation used for factors affecting Total Accruals (TA) is calculated is as follows:

$$
T A_{i t}=\beta_{0}+\beta_{1} \frac{1}{A_{i t}}+\beta_{2} \frac{\Delta R E V_{i t}-\Delta A R_{i t}}{A_{i t-1}}+\beta_{3} \frac{P P E_{i t}}{A_{i t-1}}+\beta_{4} \frac{R O A_{i t}}{A_{i t-1}}+\varepsilon_{i t},
$$

where $A$ denotes total assets at year end, $\triangle R E V$ represents the change in the company's revenue $i$ in year $t$ from the previous year $t-1, \triangle A R$ represents the change in the accounts receivable of the company $i$ in year $t$ from the previous year $t-1, P P E$ represents fixed assets (property, plant and equipment) during the year, $R O A$ represents the rate of return on assets, and $\varepsilon$ denotes to residuals or error term in the regression equation.

\section{The value Nondiscretionary Accruals}

At this stage, the estimated values of the regression model parameters (i.e. $\beta_{0}, \ldots, \beta_{4}$ ) in the previous stage are used to determine the value of Nondiscretionary Accruals for each company separately and during each year of research, by the following formula:

$$
N D A_{i t}=\widehat{\beta}_{0}+\widehat{\beta}_{1} \frac{1}{A_{i t}}+\widehat{\beta}_{2} \frac{\Delta R E V_{i t}-\Delta A R_{i t}}{A_{i t-1}}+\widehat{\beta}_{3} \frac{P P E_{i t}}{A_{i t-1}}+\widehat{\beta}_{4} \frac{R O A_{i t}}{A_{i t-1}}+\varepsilon_{i t},
$$

where $N D A$ represents the value of Nondiscretionary Accruals.

Discretionary Accruals (DAC)

The $D A$ is estimated by the difference between the Total Accruals (TA) and Nondiscretionary Accruals (NDA) as follow:

$$
D A C_{i t}=T A_{i t}-N D A_{i t}
$$

$D A C_{i t}$ is also used as an indicator of earning management, where the positive value of the discretionary accruals refers to the practice of the company earning management; for the purpose of increasing income, while the negative value refers to the practice of earning management for the purpose of reducing income, but if the value of discretionary accruals equals to zero or close to zero, this indicates the lack of earning management .

\section{Share Price (SP)}

The average share price is calculated by the following equation (Motokawa, 2015):

$$
S P_{i t}=\beta_{0}+\beta_{1} B V_{i t}+\beta_{2} E P S_{i t},
$$

where $S P_{i t}$ denotes the average share price, $B V_{i t}$ represents average book value per share, and $E P S_{i t}$ represents the average earnings per share.

\section{Firm Value}

The researchers used the (Tobin's Q) model to measure the firm value as it is considered the most accurate and used value in accounting research (Al-Matari et al., 2014) and it is calculated as follows:

$$
\text { Tobin's } Q=A T+M V E-B V E-D T \div A T \text {, }
$$

where $A T$ is the book value of assets, $M V E$ is the market value of common stock, $B V E$ is the book value of common equity, and $D T$ represents balance sheet deferred taxes.

\subsection{Measurement of Independent variable}

Researchers depend on measuring the independent variable i.e. disclosure quality of the integrated business reports on building up a disclosure index consisting of 45 items in 8 groups equally weighted, which includes most of the information that should 
be contained in the integrated report (Appendix 1). Moreover, researchers depend on the framework of the Integrated International Reporting Council (IIRC) $(2011,2013)$ and the models designed by Zhou et al. (2017), Maria et al. (2017) and Cheng et al. (2016).

\subsection{Measurement of control variables}

There are certain variables other than accounting disclosure of the integrated business reports that may affect both predictive power of accounting information and firm value. Therefore, researchers adopted the following variables to control the relationship between dependent and independent variables.

Table 1

Summarizes the definitions of the Control variables

\begin{tabular}{cl}
\hline Variable & \multicolumn{1}{c}{ Measurement } \\
\hline SIZE & Firm size, measured using the natural logarithm of total assets. \\
LEV & $\begin{array}{l}\text { Leverage, measured as total long-term liabilities divided by total equity. } \\
\text { Market-to-book value ratio, indicates to growth opportunities, measured as the market value of the firm divided by the book value of } \\
\text { the firm. }\end{array}$ \\
ROA & $\begin{array}{l}\text { Return on assets as proxy for financial performance, measured as net income before extraordinary items divided by total assets. } \\
\text { Corporate Governance, to measure the quality of corporate governance within the company through the following criteria; Independ- } \\
\text { ence of more than half of the board members, Non-duplication of the role of the Chief Executive Officer, Number of members of the } \\
\text { Audit Committee (at least three members), Independence of the members of the Committee, the availability of financial and account- } \\
\text { ing expertise within the members committee, and the number of meetings of the Audit Committee at least (4) times annually }\end{array}$ \\
& $\begin{array}{l}\text { Size of Auditing Office, dummy variable with a value of (1) if the company is associated with one of the major auditing firms, and } \\
\text { the value of }(0) \text { if does not. }\end{array}$ \\
\hline AUD &
\end{tabular}

\subsection{Testing Hypotheses}

To test research hypotheses, the researchers used the following regression models to determine the effect of integrated business reporting quality on the predictive power of accounting information and the firm value.

i. Integrated Business Reporting Quality and Accounting Conservatism:

$$
\text { Cons }=a+\beta_{1} \text { IRQ }+\beta_{2} \mathrm{SIZ}+\beta_{3} \mathrm{LEV}+\beta_{4} \mathrm{MB}+\beta_{5} \mathrm{ROA}+\beta_{6} \mathrm{CG}+\beta_{7} \mathrm{AUD}+\varepsilon .
$$

ii. Integrated Business Report Quality and Discretionary Accruals:

$$
\mathrm{DAC}=\mathrm{a}+\beta_{1} \mathrm{IRQ}+\beta_{2} \mathrm{SIZ}+\beta_{3} \mathrm{LEV}+\beta_{4} \mathrm{MB}+\beta_{5} \mathrm{ROA}+\beta_{6} \mathrm{CG}+\beta_{7} \mathrm{AUD}+\varepsilon .
$$

iii. Integrated Business Report Quality and Average Share Price:

$$
\mathrm{SP}=\mathrm{a}+\beta_{1} \mathrm{IRQ}+\beta_{2} \mathrm{SIZ}+\beta_{3} \mathrm{LEV}+\beta_{4} \mathrm{MB}+\beta_{5} \mathrm{ROA}+\beta_{6} \mathrm{CG}+\beta_{7} \mathrm{AUD}+\varepsilon .
$$

iv. Integrated Business Reports Quality and the Firm Value :

$$
\text { Tobin's } \mathrm{Q}=\mathrm{a}+\beta_{1} \mathrm{IRQ}+\beta_{2} \mathrm{SIZ}+\beta_{3} \mathrm{LEV}+\beta_{4} \mathrm{MB}+\beta_{5} \mathrm{ROA}+\beta_{6} \mathrm{CG}+\beta_{7} \mathrm{AUD}+\varepsilon
$$

where $:$ CONS = Accounting Conservatism, DAC = Discretionary accruals, $\mathrm{SP}=$ Average Share Price, Tobin's Q = Firm Value, IRQ = Quality of integrated business report, SIZ = Firm Size, LEV = Leverage, MB = Market-to-book value ratio, $\mathrm{ROA}=$ Rate of Asset, $\mathrm{CG}=$ Corporate Governance and AUD $=$ Size of Auditing Offices .

\subsection{Research Population and Sample}

Research population is represented by the companies listed in the Egyptian Stock Exchange during the research period (from 2015 to 2018). The sampling technique was done by purposive sampling taking into consideration the following criteria,

a) Availability of financial reports and data of the companies during the research period.

b) Existing an interest by companies towards the different dimensions of integrated business reports such as the environmental dimension, social dimension, economic dimension, governance dimension, ethical dimension, and risk management.

c) Companies should not have been merged, bankruptcy or reorganized within the period of (5) years prior to the current study.

d) companies do not belong to financial institutions (banks, insurance companies), because of their special nature, and subject to certain procedures by the Central Bank of Egypt.

Taking into consideration the above criteria, 28 companies were selected from the total number of 30 companies registered in the EGX 30 index. The study used only secondary data from EGX 30 index during the study period to measure the effect of disclosure quality of integrated business reports on the predictive power of accounting information and firm value, therefore, the validity and reliability test is not needed in this study. Data were collected based on several sources for analyzing the 
content of the financial reports during the study period, which are available on the following websites, www.Argamm.com, Mubasher Info website www.mumbasher.info and Egypt for Information Dissemination www.egidegypt.com, Egyptian Stock Exchange www.egx.com.eg.

\section{Analysis of the results and testing hypotheses}

Table 2 shows the descriptive statistics associated with independent, dependent and control variables.

Table 2

The results of descriptive statistics

\begin{tabular}{llllll}
\hline Part 1: Continuous variables : & & & & & \\
\hline Variables & $\mathrm{N}$ & Minimum & Maximum & Mean & Std. Deviation \\
\hline IRO & 112 & .18 & .54 & .4020 & .09031 \\
CONS & 112 & .21 & 7.52 & 3.4475 & 1.74772 \\
DAC & 112 & .12 & .51 & .3313 & .09854 \\
SP & 112 & 19.00 & 250.00 & $1.3429 \mathrm{E} 2$ & 57.12506 \\
TOBINS & 112 & 2.11 & 5.96 & 4.0393 & 1.00945 \\
SIZE & 112 & 7.11 & 12.84 & 10.0621 & 1.50898 \\
LEV & 112 & 3.27 & 8.64 & 5.6538 & 1.15893 \\
MB & 112 & .03 & 4.96 & 2.9598 & 1.44866 \\
ROA & 95 & .11 & .52 & .3495 & .11234 \\
CG & 112 & 2.00 & 5.00 & 3.6607 & 1.02714 \\
\hline Part 2: Dummy variable : & & & & & \\
Variables & 0 & & 1 & & $38 \%$ \\
AUD & 69 & $62 \%$ & 43 & & \\
\hline
\end{tabular}

As far as continuous variables are concern, Table 2 depicts a decreasing trend in the disclosure quality of integrated business report, as the highest value of continuous variables reached $54 \%$ and the lowest value registered $18 \%$ with an overall average $(40.2 \%)$. It's worth mentioning to conclude that the results obtained in our research was different compared with other business environments, for instance, in Egyptian environment the overall average for disclosure quality percentage of integrated business report registered (37,4\%) (Melegi, 2015), whereas, Vitolla et al. (2019) registered an overall average for disclosure quality of integrated business report $56.2 \%$. Table 2 also shows the overall average of accounting conservatism and discretionary accruals as 3.4 and 3.31), respectively; while the largest and the lowest share prices during the study period were 250 and 19, respectively; and finally the overall average firm value was registered as 4.04. Moreover, Table 2 provides the overall average of normal logarithm of asset size LEV, MB as 10.06, 5.65 and 0.29, respectively. The highest value of ROA during the study period was $52 \%$ whereas, the lowest value was $11 \%$; and finally, the overall average of CG was 0.349 . Pertaining to dummy variables, Table 2 shows a decrease in the number of companies associated with the major audit offices during the study period, where the number of views was 43 views or $38 \%$. Pearson correlation coefficient was used to determine the strength and direction of the relationship between the disclosure quality of integrated business reports (DQIBR) and the predictive value of accounting information and the firm value. Table 3 indicates a positive correlation relationship between disclosure quality of integrated business report with accounting conservatism, share price, and firm value; while there is a negative relationship with discretionary accruals. Concerning to control variables, it is clear from Table 3 that the size of the company, MB, ROA, and size of auditing office were positively correlated with accounting conservatism, share price, and firm value, while these variables were negatively correlated with discretionary accruals. Moreover, leverage depicts a negative correlation with accounting conservatism, share price, and firm value, while it shows a positive correlation with discretionary accruals. Indeed, these results were matched by Iredele (2019).

Table 3

The results of the correlation

\begin{tabular}{|c|c|c|c|c|c|c|c|c|c|c|c|}
\hline & IRO & CONS & DAC & SP & TOBINS & SIZE & $\mathrm{LEV}$ & $\mathrm{BM}$ & $\mathrm{ROA}$ & $\mathrm{CG}$ & AUD \\
\hline IRO & 1.00 & & & & & & & & & & \\
\hline CONS & $.738 * *$ & 1.00 & & & & & & & & & \\
\hline DAC & $-.684 * *$ & $-.815 * *$ & 1.00 & & & & & & & & \\
\hline SP & $.544 * *$ & $.656^{* *}$ & $-.582 * *$ & 1.00 & & & & & & & \\
\hline TOBINS & $.759 * *$ & $.825^{* *}$ & $-.855 * *$ & $.700^{* *}$ & 1.00 & & & & & & \\
\hline SIZE & $.698 * *$ & $.871 * *$ & $-.787 * *$ & $.750 * *$ & $.821 * *$ & 1.00 & & & & & \\
\hline LEV & $-.765 * *$ & $-.807 * *$ & $.803 * *$ & $-.681 * *$ & $-.873 * *$ & $-.760 * *$ & 1.00 & & & & \\
\hline MB & $.785^{* *}$ & $.877 * *$ & $-.832 * *$ & $.648 * *$ & $.825 * *$ & $.855^{* *}$ & $-.807 * *$ & 1.00 & & & \\
\hline ROA & $.700 * *$ & $.845^{* *}$ & $-.770 * *$ & $.585 * *$ & $.791 * *$ & $.858 * *$ & $-.758 * *$ & $.860 * *$ & 1.00 & & \\
\hline $\mathrm{CG}$ & $.677 * *$ & $.758 * *$ & $-.723 * *$ & $.579 * *$ & $.761 * *$ & $.753 * *$ & $-.767 * *$ & $.817 * *$ & $.739 * *$ & 1.00 & \\
\hline AUD & $.668 * *$ & $.675 * *$ & $-.694 * *$ & $.588 * *$ & $.775 * *$ & $.682 * *$ & $-.718^{* *}$ & $.709 * *$ & $.696 * *$ & $.675 * *$ & 1.00 \\
\hline
\end{tabular}

Note: variables $* * *$ indicates significance levels at $(0.01)(0.05)$ respectively.

\subsection{Testing Hypothesis and Discussing Results}

Hypothesis test 1: There is a statisticlly positve association between the quality disclosure of the integrated business reports and the accounting conservatism. 
Table 4 provides the analysis of regression models, which shows that the value of coefficient (B) i.e. (0.122) denotes to the quality disclousre of integrated business report indicating to a positive effect, which is ultimately assures that the quality disclousre of integrated business report leads to increase accounting conservatizm level. Furthermore, T-test, value is (0.083) at significance level (0.034), which is less than (0.05) and confirms the first hypothesis. The result is consistent with findings of Cheng and Kung (2016) as they concluded that corporate disclosure of integrated business reports enhances ethical obligations, restricts the opportunistic behavior of managers and leads to increase accounting conservatizm. Based on the above, the first regression model can be formulated as follows:

$$
C O N S=1.171+0.122(I R Q)+0.308(S I Z E)-0.447(L E V)+0.236(M B)+3.567(R O A)+0.035(C G)+0.132(A U D)
$$

Table 4 shows the association between DQIBR and accounting conservatism.

\section{Table 4}

The results of regression analysis

\begin{tabular}{|c|c|c|c|c|c|c|}
\hline \multirow[t]{2}{*}{ Model } & & \multicolumn{2}{|c|}{ Unstandardized Coefficients } & \multicolumn{2}{|c|}{ Standardized Coefficients $\mathrm{t}$} & \multirow[t]{2}{*}{ Sig. } \\
\hline & & $\mathrm{B}$ & Std. Error & Beta & & \\
\hline \multirow{8}{*}{1} & (Constant) & 1.171 & 1.574 & & .744 & .459 \\
\hline & IRQ & .122 & 1.468 & .007 & .083 & .034 \\
\hline & SIZE & .308 & .109 & .270 & 2.835 & .006 \\
\hline & LEV & -.447 & .137 & -.303 & -3.265 & .002 \\
\hline & MB & .236 & .148 & .186 & 1.600 & .113 \\
\hline & ROA & 3.567 & 1.553 & .266 & 2.297 & .024 \\
\hline & CG & .035 & .128 & .021 & .276 & .783 \\
\hline & AUD & .132 & .219 & $.044-$ & .600 & .550 \\
\hline
\end{tabular}

a. Dependent Variable: CONS

Hypothesis test 2: There is a statisticlly negative association between the quality disclosure of the integrated business reports and the discretionary accruals.

Table 5 provides the analysis of regression models, it shows that the value of coefficient (B) i.e. (-0.064) denotes to the quality disclousre of integrated business report indicating to a negative effect, which is ultimately assures that the quality disclousre of integrated business report leads to decrease discretionary accruals. Furthermore, T-test, value is $(-0.600)$ at significance level of 0.04 , which is less than 0.05 which confirms the second hypothesis. The results is also consistent with the results provided by Sanchea and Gamez (2017) as they concluded that integrated business reports may lead to reduce information asymmetry, reduce agency problems, reduce discretionary accruals and thus increase quality of financial reporting. Based on the above, the second regression model can be formulated as follows:

$$
D A C=0.279-0.064(\text { IRQ })-0.001(S I Z E)+0.025(L E V)-0.023(M B)-0.233(R O A)-0.011(C G)-0.020(A U D)
$$

Table 5 shows the association between DQIBR and discretionary accruals.

\section{Table 5}

The results of the regression analysis between DQIBR and discretionary accruals

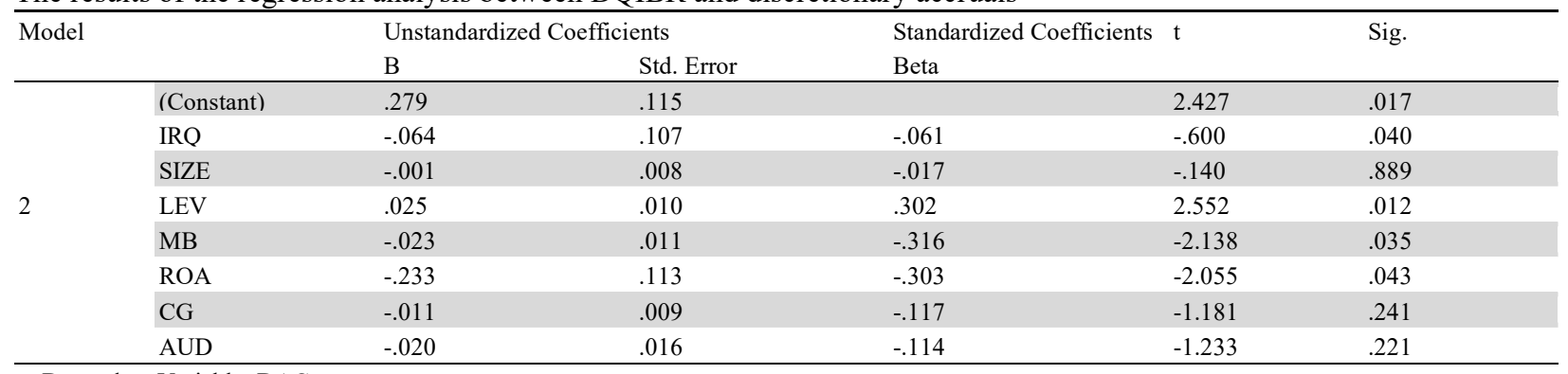

a. Dependent Variable: DAC

Hypothesis test 3: There is a statisticlly positve association between the quality disclosure of the integrated business reports and the share price.

Table 6 provides the analysis of regression models, which shows that the value of coefficient (B) i.e. (67.62) denotes to the quality disclousre of integrated business report indicating to a positve effect, which is ultimately assures that the quality disclousre of integrated business report leads to increase share prices. Furthermore, T-test, value is (0.836) at significance level (0.02), which is less than (0.05) and proves the third hypothesis. The result is consistent with the results provided by Cortesi and Vena (2019) as they concluded that integrated business reports may lead to enhance disclousre quality and reduce 
information asymmetry and increase profitability. Based on the above, the third regression model can be formulated as follows:

$$
\mathrm{SP}=1.323+67.622(\mathrm{IRQ})+32.940(\mathrm{SIZE})-21.121(\mathrm{LEV})+2.305(\mathrm{MB})+188.866(\mathrm{ROA})+.732(\mathrm{CG})+9.071(\mathrm{AUD})
$$

Table 6 shows the association between DQIBR and share price.

\section{Table 6}

The results of regression analysis between DQIBR and Share Price

\begin{tabular}{|c|c|c|c|c|c|c|}
\hline \multirow[t]{2}{*}{ Model } & & \multicolumn{2}{|c|}{ Unstandardized Coefficients } & \multirow{2}{*}{$\begin{array}{l}\text { Standardized Coefficients } \\
\text { Beta }\end{array}$} & \multirow[t]{2}{*}{ t } & \multirow[t]{2}{*}{ Sig. } \\
\hline & & $\mathrm{B}$ & Std. Error & & & \\
\hline \multirow{8}{*}{3} & (Constant) & 1.323 & 86.752 & & .015 & .988 \\
\hline & IRQ & 67.622 & 80.929 & .097 & .836 & 02 \\
\hline & SIZE & 32.940 & 5.983 & .757 & 5.506 & .000 \\
\hline & LEV & -21.121 & 7.538 & -.376 & -2.802 & .006 \\
\hline & MB & 2.305 & 8.141 & .047 & .283 & .778 \\
\hline & ROA & 188.866 & 85.600 & .369 & 2.206 & .030 \\
\hline & CG & .732 & 7.041 & .012 & .104 & .917 \\
\hline & AUD & 9.071 & 12.085 & .079 & .751 & .455 \\
\hline
\end{tabular}

a. Dependent Variable: SP

Hypothesis test 4: There is a statisticlly positve association between the quality disclosure of the integrated business reports and the firm value.

Table 7 provides the analysis of regression models and shows the value of coefficient (B) i.e (0.744) denoting to the quality disclousre of integrated business report indicating to a positve effect, which is ultimately assures that the quality disclousre of integrated business report leads to increase firm value. Furthermore, T-test, value is (0.861) at significance level (0.016), which is less than (0.05) and confirms the fourth hypothesis. In fact, the result is consistent with other results (e.g. Pavlopoulos et al., 2019; Usanova \& Khakimzyanova, 2017) as they concluded that the disclosure quality of integrated business report contribute to improve firm value, quality of accounting information and quality of profitability. Based on the above, the fourth regression model can be formulated as follows:

$$
\text { TOBIN,S Q=3.517+.744 (IRQ) +.161 (SIZE) -.336(LEV) +1.24 (MB)+.144(ROA) + 0.008(CG) + .370(AUD) }
$$

Table 7 shows the association between DQIBR and firm value.

Table 7

\begin{tabular}{|c|c|c|c|c|c|c|}
\hline \multirow{2}{*}{\multicolumn{2}{|c|}{ Model }} & \multicolumn{2}{|c|}{ Unstandardized Coefficients } & \multirow{2}{*}{\multicolumn{2}{|c|}{$\begin{array}{l}\text { Standardized Coefficients } \mathrm{t} \\
\text { Beta }\end{array}$}} & \multirow[t]{2}{*}{ Sig. } \\
\hline & & $\mathrm{B}$ & Std. Error & & & \\
\hline \multirow{8}{*}{4} & (Constant) & 3.517 & .926 & & 3.799 & .000 \\
\hline & IRQ & .744 & .864 & .066 & .861 & .016 \\
\hline & SIZE & .161 & .064 & .231 & 2.525 & .013 \\
\hline & LEV & -.336 & .080 & -.373 & -4.174 & .000 \\
\hline & MB & .124 & .087 & .159 & 1.424 & .158 \\
\hline & ROA & .144 & .914 & .017 & .157 & .876 \\
\hline & $\mathrm{CG}$ & .008 & .075 & .008 & .101 & .920 \\
\hline & AUD & .370 & .129 & .200 & 2.868 & .005 \\
\hline
\end{tabular}

The results of the regression analysis between DQIBR and Firm Value

a. Dependent Variable: TOBINS

\section{Conclusion}

There is no doubt that integrated business reporting has become a prominent approach for business organization (Havlová, 2015). This approach enables all types of reporting features inside it (Morros, 2016). Therefore, accounting literature urges to adopt the approach of integrated business reports by firms as a mean of delivering financial and non-financial information on social and environmental responsibility and corporate governance, as well as information on corporate strategy, provided that this information, whether historical or future, has to be clearly formulated, concise, coordinated and feasible to enhance the predictive power of accounting information and achieve comparability (Rinaldi et al., 2018; Lopes \& Coelho, 2018) . 
Researchers in this study endeavor to measure the effect of disclosure quality of integrated business reports on the predictive power of accounting information and firm's value in the Egyptian stock market. To achieve this, researchers adopted several models to measure the association between research variables; the independent variable representing disclosure quality of the integrated business reports, and dependent variables which are representing the predictive power of accounting information which has been measured by adopting three different methodologies; (Accounting Conservatism, Share Prices, and Discretionary Accruals) and finally, control variables which are representing (Firm size, Leverage Market-to-book value ratio, Return on assets, Corporate Governance, and Size of Auditing Office). Concerning to firm value, the researchers used Tobin's $\mathrm{Q}$ model to measure the relation between the quality disclosure of the integrated business reports and the firm value.

Descriptive statistics has revealed a decreasing trend in the disclosure quality of integrated business report with an overall average of $40.2 \%$. It's worth mentioning to conclude that the results obtained in our research was different compared with other business environments, for instance, in Egyptian environment the overall average for disclosure quality percentage of integrated business report was measured as 37.4\% (Melegi, 2015), whereas, Vitolla et al. (2019) an overall average of 56.2\%. The overall average of accounting conservatism and discretionary accruals registered as 3.4 and 3.31, respectively; while the largest and the lowest share prices during the study period were 250 and 19, respectively per share; and finally the overall average firm value was observed as 4.04 . We believe that adopting the integrating business reporting approach in middle east countries is still in the preliminary stages and this is due to lack of adequate standards or guidelines to regulate the accounting disclosure of integrated business reports. To date, there is no agreed standardized format for integrated business reporting, particularly in developing country environments like Egypt. Thus, IIRC in 2018 determined the global adoption phase A and making integrated reports the norm, since the evidence for the benefits of integrated business reports is sparse (Barth et al., 2017), this needs further in-depth research and analysis to measure the effects on the quality of reporting, especially in developing countries environments. Concerning to research hypothesis; the results obtained show clearly that the quality disclousre of integrated business report could lead to increase accounting conservatism and share prices, and this is what has been supported by Cheng and Kung (2016) and Cortesi and Vena (2019), whereas the statistics analysis reports a negative effect towards discretionary accruals indicating that the quality disclousre of integrated business report leads to decrease in discretionary accruals, The results is consistent with Sanchea and Gamez (2017).

Pertaining to the association between the quality disclosure of the integrated business reports and the firm value, the result of regression model shows a positve effect, which is ultimately assures that the quality disclousre of integrated business report leads to increase firm value. The results are consistent with Pavlopoulos et al. (2019) and Usanova and Khakimzyanova (2017) as they concluded that the disclosure quality of integrated business report contribute to improve firm value, quality of accounting information and quality of profitability. In terms of contributions, the present research provides important information that will help accounting standards makers and decision makers in the Egyptian business environment to take decisions, legislation or rules, which will motivate companies to pay attention to the quality of disclosure of integrated business reports to increase transparency and give a good picture to stakeholders, which will reflect a positive impact on firm value and the national economy as a whole.

A limitation of our research is that it was associated with the study sample size and the methods of measuring the variables used. In additions to that the study period was relatively short, which may affect the results. The study also did not address all the methods and approaches used in measuring the predictive value of information. In this sense, this research can simulate further research on the topic focusing on other dimensions.

\section{References}

Arya, A., Frimor, H., \& Mittendorf, B. (2010). Discretionary disclosure of proprietary information in a multisegment firm. Management Science, 56(4), 645-658.

Badawi, H. (2017). The effect of ownership structure and level of social responsibility disclosure on company's value - An applied study on listed Egyptian companies, auditing \& accounting. Journal for Arabia Universities Unoion, Commrce College, Bani Swaif University, 5(2), 171-206.

Barth, M. E., Cahan, S. F., Chen, L., \& Venter, E. R. (2017). The economic consequences associated with integrated report quality: Capital market and real effects. Accounting, Organizations and Society, 62, 43-64.

Beaver, W. H., \& Ryan, S. G. (2000). Biases and lags in book value and their effects on the ability of the book-to-market ratio to predict book return on equity. Journal of Accounting Research, 38(1), 127-148.

Cheng, C. L., \& Kung, F. H. (2016). The effects of mandatory corporate social responsibility policy on accounting conservatism. Review of Accounting and Finance, 15(1), 2-20.

Cheng, M., Green, W., Conradie, P., Konishi, N., \& Romi, A. (2014). The international integrated reporting framework: key issues and future research opportunities. Journal of International Financial Management \& Accounting, 25(1), 90-119.

Cormier, D., Magnan, M., \& Van Velthoven, B. (2005). Environmental disclosure quality in large German companies: economic incentives, public pressures or institutional conditions?. European Accounting Review, 14(1), 3-39.

Cortesi, A., \& Vena, L. (2019). Disclosure quality under integrated reporting: a value relevance approach. Journal of Cleaner Production, 220, 745-755.

Al-Matari, E. M., Al-Swidi, A. K., \& Fadzil, F. H. B. (2014). The measurements of firm performance's dimensions. Asian Journal of Finance \& Accounting, 6(1), 24.

Fuhrmann, S., Ott, C., Looks, E., \& Guenther, T. W. (2017). The contents of assurance statements for sustainability reports and information asymmetry. Accounting and Business Research, 47(4), 369-400. 
Haryono, U., \& Iskandar, R. (2015). Corporate social performance and firm value. International Journal of Business and Management Invention, 4(11), 69-75.

Havlová, K. (2015). What integrated reporting changed: the case study of early adopters. Procedia Economics and Finance, 34 , 231-237.

International Integrated Reporting Council (IIRC) (2011). Towards Integrated Reporting: Communicating Value in the 21st Century. Discussion Paper, International Integrated Reporting Council, available at: www.theiirc.org, accessed 19 July 2015.

International Integrated Reporting Council (IIRC) and Blacksun (2014). Realizing the Benefits: The Impact of Integrated Reporting', available at: http://www.theiirc.org/wp content/uploads/2014/09/IIRC.Black_.Sun_.Research.IR_.Impact.Single. pages.18.9.14.pdf, accessed 19 July 2015.

International Integrated Reporting Council (IIRC). (2013) International Integrated Reporting Framework.

International Integrated Reporting Council IIRC (2015). Creating Value: Value to Investors.

Iredele, O. O. (2019). Examining the association between quality of integrated reports and corporate characteristics. Heliyon, 5(7), e 01932 .

Martínez-Ferrero, J., Garcia-Sanchez, I. M., \& Cuadrado-Ballesteros, B. (2015). Effect of financial reporting quality on sustainability information disclosure. Corporate Social Responsibility and Environmental Management, 22(1), 45-64.

Jones, J. J. (1991). Earnings management during import relief investigations. Journal of Accounting Research, 29(2), $193-228$.

Kılıç, M., \& Kuzey, C. (2018). Assessing current company reports according to the IIRC integrated reporting framework. Meditari Accountancy Research, 26(2), 305-333.

Kothari, S. P., Leone, A. J., \& Wasley, C. E. (2005). Performance matched discretionary accrual measures. Journal of Accounting and Economics, 39(1), 163-197.

Lee, K. W., \& Yeo, G. H. H. (2016). The association between integrated reporting and firm valuation. Review of Quantitative Finance and Accounting, 47(4), 1221-1250.

Li, Y., Gong, M., Zhang, X. Y., \& Koh, L. (2018). The impact of environmental, social, and governance disclosure on firm value: The role of CEO power. The British Accounting Review, 50(1), 60-75.

Macias, H. A., \& Farfan-Lievano, A. (2017). Integrated reporting as a strategy for firm growth: multiple case study in Colombia. Meditari Accountancy Research, 25(4), 605-628.

Mahmood, M., \& Humphrey, J. (2013). Stakeholder expectation of corporate social responsibility practices: a study on local and multinational corporations in Kazakhstan. Corporate Social Responsibility and Environmental Management, 20(3), 168-181.

García-Sánchez, I. M., \& Noguera-Gámez, L. (2017). Integrated reporting and stakeholder engagement: The effect on information asymmetry. Corporate Social Responsibility and Environmental Management, 24(5), 395-413.

Dal Maso, L., Liberatore, G., \& Mazzi, F. (2017). Value relevance of stakeholder engagement: The influence of national culture. Corporate Social Responsibility and Environmental Management, 24(1), 44-56.

Morros, J. (2016). The integrated reporting: A presentation of the current state of art and aspects of integrated reporting that need further development. Intangible Capital, 12(1), 336-356.

Motokawa, K. (2015). Human capital disclosure, accounting numbers, and share price. Journal of Financial Reporting and Accounting, 13(2), 159-178.

Pavlopoulos, A., Magnis, C., \& Iatridis, G. E. (2019). Integrated reporting: An accounting disclosure tool for high quality financial reporting. Research in International Business and Finance, 49, 13-40.

Qiu, Y., Shaukat, A., \& Tharyan, R. (2016). Environmental and social disclosures: Link with corporate financial performance. The British Accounting Review, 48(1), 102-116.

Rinaldi, L., Unerman, J., \& De Villiers, C. (2018). Evaluating the integrated reporting journey: insights, gaps and agendas for future research. Accounting, Auditing \& Accountability Journal, 31(5), 1294-1318.

Schuler, D. A., \& Cording, M. (2006). A corporate social performance-corporate financial performance behavioral model for consumers. Academy of Management Review, 31(3), 540-558.

Sharaf, I.A.I. (2015). The impact of non-financial disclosure through integrated business reporting on investors' assessment of the company's value creation - An empirical study. Commerce Journal for Scientific Research, Faculty of Commerce, Alexandria University, 52(2), 121--163.

The Egyptian Stock Exchange, (2016). Guidelines for Disclosure of Sustainability Performance by Listed Companies. pp. 139. Available at: www.egx.com.eg

Usanova, D. S., \& Khakimzyanova, L. K. (2017). Integrated Reporting as a Factor of Firm's Value Growth. Journal of Economic \& Management Perspectives, 11(3), 1594-1599.

Cortesi, A., \& Vena, L. (2019). Disclosure quality under integrated reporting: a value relevance approach. Journal of Cleaner Production, 220, 745-755.

Vitolla, F., Raimo, N., Rubino, M., \& Garzoni, A. The impact of national culture on integrated reporting quality. A stakeholder theory approach. Business Strategy and the Environment, 1-14

Zeng, T. (2016). Corporate social responsibility, tax aggressiveness, and firm market value. Accounting Perspectives, 15(1), 730.

Zhong, Y., \& Li, W. (2017). Accounting conservatism: A literature review. Australian Accounting Review, $27(2), 195-213$.

Zhou, S., Simnett, R., \& Green, W. (2017). Does integrated reporting matter to the capital market?. Abacus, 53(1), 94-132. 


\section{Appendix 1}

Accounting Disclosure Indicators of Integrated Business Reports

\begin{tabular}{|c|c|}
\hline & 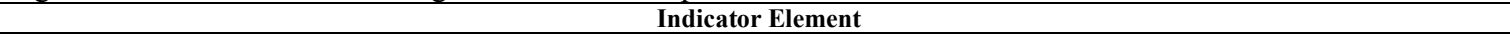 \\
\hline & Organizational Overview and External Environment \\
\hline 1 & Vision, mission, values and culture of the firm and the conditions surrounding it. \\
\hline 2 & Competition Conditions and market situation \\
\hline 3 & $\begin{array}{l}\text { The effect of external factors on the corporate (economic stability, globalization, industry trends, market forces, technology changes, and polit- } \\
\text { ical challenges. }\end{array}$ \\
\hline 4 & Ability to create value in the short, medium and long term \\
\hline \multirow[t]{2}{*}{5} & Summary of statistics \\
\hline & Corporate Governance \\
\hline 6 & Description of Corporate Governance \\
\hline 7 & Governance Structure \\
\hline 8 & Governance and strategic decisions \\
\hline 9 & Rewards and Performance \\
\hline \multirow[t]{2}{*}{10} & The role of governance structure in value creation \\
\hline & Business Model \\
\hline 11 & Determining the business model \\
\hline 12 & Setting Company Goals \\
\hline 13 & Description of activities, markets, products and services \\
\hline 14 & Attitude to Risks \\
\hline 15 & Link business model to other content elements (strategy, risk, opportunity and performance) \\
\hline \multirow[t]{2}{*}{16} & Information provided by the integrated business report (active business, output, input, stock) \\
\hline & Risks and Opportunities \\
\hline 17 & Opportunities and risks that affect an entity's ability to create value \\
\hline 18 & $\begin{array}{l}\text { Information on the main risks facing the corporate which includes the main risks, political risks, financial, environment, information technol- } \\
\text { ogy, human resources and reputational risks. }\end{array}$ \\
\hline 19 & Identify sources of risks and opportunities, assess potential risks or opportunities, and determine the magnitude of impact if it occurs. \\
\hline 20 & Action taken to minimize risks, manage key risks or create value from key opportunities \\
\hline 21 & Is the principle of materiality used to disclose any material risks or changes that affect an entity's ability to create value? \\
\hline \multirow[t]{2}{*}{22} & Describe key relationships with internal and external stakeholders (needs and expectations) \\
\hline & Strategy and Resource Allocation \\
\hline 23 & Strategic objectives are short, medium, and long-term, and the way to achieve them. \\
\hline 24 & Plans for resource allocation. \\
\hline 25 & Linking the enterprise strategy to resource allocation plans and the changes needed to implement the strategy. \\
\hline 26 & Consultations with stakeholders \\
\hline 27 & Competitive advantage and ability to create value \\
\hline \multirow[t]{2}{*}{28} & Risk management in relation to key resources \\
\hline & Performance \\
\hline 29 & Key performance indicators for the economic, environmental, social and governance dimension. \\
\hline 30 & Information on customer satisfaction, shareholder return, value creation, employment opportunities, and staff development. \\
\hline 31 & Key relationships with stakeholders and the extent to which an entity responds to their needs. \\
\hline \multirow[t]{2}{*}{32} & $\begin{array}{l}\text { To what extent the report combines financial and non-financial information (economic, environmental, social, governance, ethical and risk } \\
\text { performance) }\end{array}$ \\
\hline & Future Outlook \\
\hline 33 & Opportunities, challenges and uncertainties that an entity may face in pursuing its strategy \\
\hline 34 & Response to challenges and uncertainties that are proposed to arise \\
\hline 35 & Possible impacts of the business model and future performance. \\
\hline 36 & Impacts of the external environment, risks and opportunities on the achievement of strategic objectives. \\
\hline 37 & Potential Impacts, Affordability and Value Creation over Time \\
\hline 38 & Results indicate future expectations \\
\hline 39 & Estimates \\
\hline \multirow[t]{2}{*}{40} & Balance of interests, short-, medium- and long-term goals \\
\hline & Basis of Preparation and Presentation \\
\hline 41 & The Integrated Report sets the disclosure limits \\
\hline 42 & The integrated report provides a summary of the process of determining the relative importance and key estimates adopted. \\
\hline 43 & The risks and material consequences associated with stakeholders are included in the report, creating value. \\
\hline 44 & Summary of the important frameworks and methods used to identify and evaluate the substantive issues included in the report. \\
\hline 45 & The entity determines what should be included in the integrated report. \\
\hline
\end{tabular}

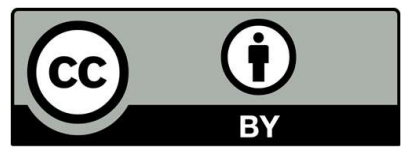

(C) 2020 by the authors; licensee Growing Science, Canada. This is an open access article distributed under the terms and conditions of the Creative Commons Attribution (CC-BY) license (http://creativecommons.org/licenses/by/4.0/). 